\title{
PERSEPSI ETIKA DALAM PENGGELAPAN PAJAK: BUKTI PERSEPSI DI FAKULTAS EKONOMI, UNIVERSITAS NEGERI YOGYAKARTA
}

\section{PERCEPTIONS OF ETHICS IN TAX EVASION: PERCEPTION EVIDENCE AT THE FACULTY OF ECONOMICS, YOGYAKARTA STATE UNIVERSITY}

\author{
Oleh: \\ Isroah \\ Staf Pengajar Jurusan Pendidikan Akuntansi Universitas Negeri Yogyakarta \\ Ponty S.P. Hutama \\ Staf Pengajar Jurusan Pendidikan Akuntansi Universitas Negeri Yogyakarta \\ Amanita Novi Yusita \\ Staf Pengajar Jurusan Pendidikan Akuntansi Universitas Negeri Yogyakarta
}

\begin{abstract}
Abstrak
Penggelapan pajak berdampak pada terdistorsinya prinsip-prinsip alokasi sumber daya pada pasar sempurna dan juga menghambat pembangunan, terutama dalam penyediaan infrastruktur. Penggelapan pajak di hampir semua negara berkembang begitu meluas. Penggelapan pajak telah membuat basis pajak atas pajak pendapatan menjadi sempit dan mengakibatkan begitu besarnya kehilangan potensi pendapatan pajak yang dapat digunakan untuk mengurangi beban defisit anggaran negara. Penelitian ini menguji apakah penggelapan pajak dapat dimaklumi dengan alasan etis (ethically justifiable) dan bagaimana perilaku wajib pajak ketika pemerintah dinilai/diduga melakukan korupsi.

Penelitian ini dilakukan untuk memahami perilaku wajib pajak, terutama dalam hal penggelapan pajak di lingkungan UNY. Objek dalam penelitian ini adalah dosen, karyawan mahasiswa S1, dan mahasiswa pascasarjana UNY. Penelitian ini diuji dengan merubah skor menjadi distribusi standar yang normal dan kemudian menghitung $z$-score (nilai z) untuk membuat inferensi setelah memperoleh $p$-value dari pernyataan-pernyataan dalam kuesioner, dengan tingkat signifikansi lima persen (5\%).

Penelitian ini diharapkan untuk memberi manfaat kepada penyelenggara perpajakan agar dapat dipastikan bahwa wajib pajak tidak melakukan penggelapan pajak. Penelitian ini juga diharapkan mampu mengungkap alasan-alasan mengapa pajak digelapkan dan mampu memberi pemahaman yang lebih baik mengapa wajib pajak melakukan penggelapan pajak.

Lebih jauh lagi, penelitian ini juga diharapkan untuk dapat memberikan manfaat kepada peneliti lainnya dan mahasiswa akuntansi bahwa penggelapan pajak adalah salah satu aspek penting dalam perpajakan. Diharapkan pula, penelitian ini bisa menjadi referensi untuk peneliti-peneliti selanjutnya dan para pembuat kebijakan.
\end{abstract}

Kata kunci: Penggelapan Pajak, Etika Pajak, Sistem Pajak, Perilaku dalam Membayar Pajak

\section{Abstract}

Impact on the tax evasion distorted the principles of resource allocation on the market and also hamper in development, especially in the provision of infrastructure. Tax evasion in almost all developing countries so widespread. Tax evasion has made the tax base of income tax to be cramped and caused so much loss of potential tax revenue that could be used to reduce the burden on the state budget deficit. This study examines whether tax evasion understandable ethical grounds (ethically justifiable) and how the taxpayer's behavior when governments rated/suspected of corruption. 
This study was conducted to understand the behavior of taxpayers, especially in terms of tax evasion in the Faculty of Economics, Yogyakarta State University (YSU). The object of this research is the faculty member, staff of faculty, undergraduate students, and graduate students. This study tested with changing the score to a standard normal distribution and then calculate z-score to make inferences after obtaining a $p$-value of the statements in the questionnaire, with a significance level of five percent (5\%).

This study is expected to deliver benefits to the organizers of taxation in order to ensure that the taxpayer is not to do tax evasion. This study is also expected to uncover the reasons why the tax is evaded and was able to give a better understanding of why taxpayers evade taxes.

Furthermore, this research is also expected to provide benefits to other researchers and students of accounting that tax evasion is one of the important aspects of taxation. It is also expected, this study could serve as a reference for subsequent researchers and policy-makers.

Keywords: Tax Evasion, Tax Ethics, Tax Systems, Behavioral in Taxation

\section{PENDAHULUAN \\ Latar Belakang}

Dalam pembangunan dan pertumbuhan suatu masyarakat, ketersediaan infrastruktur dasar sangatlah diperlukan. Hal ini bisa saja menjelaskan mengapa pemerintah selalu mencurahkan perhatian yang cukup dalam tetang bagaimana caranya menghimpun dana untuk pembangunan dan pencapaianpencapaian kesejahteraan sosial untuk masyarakat.

Pemerintah membutuhkan dana untuk melaksanakan dan mewujudkan tanggungjawab sosial kepada publik. Tanggung jawab sosial tersebut tidak hanya terbatas pada penyediaan infrastruktur dan pelayanan sosial. Menurut Mukur (2001), dalam pemenuhan kebutuhan dan harapan masyarakat dibutuhkan dana yang besar, dimana dana tersebut tidak bisa digalang hanya dari perorangan (individu) atau bahkan masyarakat itu sendiri. Hal ini merupakan tanggung jawab pemerintah untuk melakukan penggalangan dana dalam rangka memenuhi berbagai macam kebutuhan dasar serta dapat mendatangkan manfaat bagi warga negaranya. Salah satu cara penggalangan dana pembangunan tersebut adalah dengan memungut pajak. Oleh sebab itu, warga negara dan masyarakat tidak dapat mengesampingkan kewajiban dan tanggungjawabnya dalam membayar pajak. Membayar pajak merupakan kontribusi nyata masyarakat dan warga negara dalam pembangunan dan proses administrasinya.

Perpajakan (taxation), menurut Ogundele (1999) (dalam Fagbemi et al., 2010) adalah proses atau mekanisme dimana suatu komunitas atau sekelompok orang dikondisikan untuk berkontribusi dalam jumlah dan metode yang disepakati untuk digunakan dalam penyelenggaraan proses administrasi dan pembangunan dalam suatu masyarakat. Bisa disimpulkan bahwa dengan dana yang diperoleh dari pajak akan dapat bermanfaat untuk seluruh masyarakat. Mirip dengan definisi yang dikemukakan Ogundele (1999) (dalam Fagbemi et al., 2010) di atas, Soyode dan Kajola (2006) menyebutkan bahwa pajak adalah penggalangan sejumlah uang atau dana oleh otoritas publik untuk kepentingan publik. Nightingale (1997) juga menjelaskan bahwa penggalangan dana wajib dilakukan oleh pemerintah. Penelitianpenelitian diatas juga berkesimpulan bahwa bisa saja pembayar pajak tidak secara langsung merasakan pajak yang mereka bayar, tetapi masyarakat atau warga negara bisa memperoleh manfaat dengan mendapatkan/menikmati fasilitas pendidikan, kesehatan, dan keamanan sosial.

Dalam penelitian yang dilakukan Hutama (2011), disebutkan bahwa pajak merupakan sumber pembiayaan yang penting bagi suatu negara. Mengingat betapa pentingnya pajak bagi negara maka merupakan 
hal yang sulit untuk dibayangkan apabila hukum pajak di suatu negara tidak mempunyai pengaruh terhadap perilaku manusia. Pengaruh-pengaruh terhadap perilaku manusia tersebut merupakan hal yang sangat penting dalam sistem perpajakan yang menganut sistem self assessment, yang menjadi karakteristik hukum pajak penghasilan di Indonesia.

Oleh sebab itu, perilaku penghindaran pajak (tax avoidance) dan penggelapan pajak (tax evasion) oleh wajib pajak merupakan isu yang relevan di tengah upaya pemerintah untuk meningkatkan pendapatan negara dari sektor pajak. Menurut Heru (1997), definisi penggelapan pajak adalah pengurangan pajak yang dilakukan dengan jalan melanggar peraturan perpajakan. Sedangkan penghindaran pajak adalah usaha pengurangan pajak, namun tetap mematuhi ketentuan peraturan perpajakan seperti memanfaatkan pengecualian dan potongan yang diperkenankan maupun menunda pajak yang belum diatur dalam peraturan perpajakan yang berlaku.

Hutama (2011) juga menyebutkan bahwa sistem pajak di Indonesia menganut sistem self assessment, sehingga keadilan menjadi isu yang relevan untuk meminimalkan penggelapan atau penghindaran pajak. Supaya sistem self assessment bekerja, wajib pajak haruslah merasakan sistem pajak tersebut adil. Keadilan merupakan motivator bagi wajib pajak untuk patuh terhadap pajak (Spicer \& Becker, 1980). Selain itu, menurut Rasinski (1987) dan Eriksen \& Fallan (1996) (dalam Varosi et al., 2000), keadilan merupakan penentu kepuasan wajib pajak dengan proses politik.

Fafunwa (2005) menyebutkan bahwa infrastruktur yang diharapkan dapat dinikmati oleh pembayar pajak tersebut terkadang tidak dalam kondisi yang seharusnya. Hal ini terutama terjadi di banyak negara berkembang (Obaji, 2005), terutama seperti bahwa sistem pendidikan yang belum tertata baik, dan sistem pelayanan kesehatan yang juga masih mengkhawatirkan. Hal ini terjadi karena pembiayaan infrastruktur yang bersumber dari pajak dianggap masih belum cukup sehingga memperbesar defisit anggaran pembangunan yang diduga terjadi karena penggelapan pajak.

Sikka dan Hampton (2005) dan Olatunde (2007) (dalam Fagbemi et al., 2010) menyebutkan pula bahwa tax evasion (penggelapan pajak) adalah salah satu masalah utama yang dapat menghambat pembangunan terutama di negara berkembang untuk menjadi negara yang sejahtera sehingga mempunyai kontribusi berarti untuk perekonomian dunia. Hal ini menarik perhatian pembuat kebijakan, negara-negara barat, badan-badan internasional, dan juga para akademisi.

Fagbemi et al. (2010) menyatakan penggelapan pajak di negara berkembang begitu luas, dan sekenario ini diperparah dengan kenyataan bahwa tidak banyak usaha yang dilakukan terutama oleh pemerintah di negara-negara berkembang untuk mengukur alasan-alasan etis dari pembayar pajak, akibat yang ditimbulkan dari masalah ini, dan pada saat yang bersamaan adalah menganalisa dampak yang timbul akibat penggelapan pajak (tax evasion). Chiumya (2006) (dalam Fagbemi et al., 2010) menyebutkan, hal yang terjadi berikutnya adalah, karena suatu negara tidak dapat menggalang dana pajak yang cukup, maka pemerintah dengan segara menaikkan tarif pajak atau meminjam (berhutang) yang pada kenyataannya akan mempersulit sektor swasta dalam mengembangkan perekonomian dan juga akan masuk ke dalam debt trap (perangkap utang). Di lain pihak, penggelapan pajak berdampak dalam mendistorsi alokasi sumber daya dalam prinsip-prinsip pasar sempurna dan redistribusi pendapatan (income redistribution). Hal ini dapat menimbulkan pertumbuhan ekonomi yang stagnan dan semakin jauh dari pencapaian cita-cita pembangunan sosial 
ekonomi. Oleh sebab itu, kebutuhan untuk memahami perilaku pembayar pajak menjadi penting dan juga memahami alasan-alasan yang menyebabkan perilaku-perilaku spesifik.

Peneliti tertarik untuk mengadakan penelitian tentang aspek-aspek etis dari penggelapan pajak dengan menggunakan sampel data di Indonesia. Penelitian yang akan dilakukan adalah melakukan survei dengan instrumen yang telah dikembangkan dengan dasar pada isu-isu yang telah didiskusikan pada penelitian-penelitian sebelumnya, serta dibangun dengan argumen-argumen yang telah dibuat dan dikembangkan dalam literatur selama 500 tahun terakhir. Instrumen penelitian yang akan digunakan juga serupa dengan penelitian yang dilakukan oleh Fagbemi et al. (2010) dan penelitian yang dilakukan oleh McGee et al. (2011). McGee et al. (2011) dalam penelitiannya menyebutkan bahwa sebagian besar artikel tentang penggelapan pajak masih ditulis dalam perspektif keuangan publik. Sebagian besar artikel tersebut terutama mendiskusikan aspekaspek teknis dan dampak-dampak lanjutan dari penggelapan pajak dalam perekonomian. Dalam banyak kasus, juga banyak didiskusikan tentang bagaimana mencegah atau meminimalkan penggelapan pajak. Jumlah artikel yang mendiskusikan aspek-aspek etis penggelapan pajak masih sedikit.

\section{Rumusan Masalah}

Dalam memastikan bahwa pendapatan yang diperoleh negara dari sektor pajak tersebut mencukupi untuk pembiayaan pembangunan, adalah perlu dan penting untuk mengetahui perilaku wajib pajak atau warga negara dalam membayar pajak.

Penelitian ini mencoba untuk menjawab pertanyaan-pertanyaan berikut ini:

1. Apakah penggelapan pajak dapat dimaklumi dengan alasan etis (ethically justifiable)?
2. Bagaimana perilaku wajib pajak ketika pemerintah dinilai/diduga melakukan korupsi?

\section{Tujuan Penelitian}

Tujuan utama penelitian ini adalah:

1. Melakukan investigasi persepsi wajib pajak dalam membayar pajak untuk alasan etis

2. Melakukan observasi terhadap dampak dari dugaan praktik korupsi penyelenggara pemerintahan pada penggelapan pajak

\section{Ruang Lingkup Penelitian}

Penekanan utama dari penelitian ini adalah memperoleh bukti-bukti etis dari penggelapan pajak dengan dengan menggali respon dari mahasiswa S1 FE UNY, mahasiswa pascasarjana UNY, dosen FE UNY, dan karyawan FE UNY.

Subjek mahasiswa S1 adalah mahasiswa akuntansi semester akhir yang semuanya telah lulus matakuliah perpajakan dan peserta program Brevet Pajak di FE UNY. Demikian juga dengan subjek mahasiswa pascasarjana, yang diharapkan telah bekerja dan penghasilannya dipotong pajak penghasilan. Dengan demikian, subjek mahasiswa S1 dan S2 ini dapat mewakili partisipan yang digolongkan sebagai wajib pajak.

Varosi et al. (2000) mengungkapkan bahwa penelitian tentang kepatuhan pajak (tax compliance research) sering menggunakan mahasiswa sebagai subjek penelitian. Untuk mengatasi pertanyaan apakah latar belakang pengalaman pajak partisipan mahasiswa dianggap representatif sebagai surogasi/pengganti dari pembayar pajak, Varosi et al. menggunakan cara mengumpulkan karakteristik demografi dan latar belakang pajak yang memenuhi relevansi pembayar pajak.

Penelitian ini melakukan langkah yang serupa dengan apa yang dilakukan oleh Varosi 
et al. dengan memasukkan karakteristik pembayar pajak dalam mengumpulkan data demografi partisipan, seperti data penghasilan per bulan/tahun partisipan, status kepemilikan Nomor Pokok Wajib Pajak (NPWP), pembayaran pajak penghasilan, dan pernah atau tidaknya partisipan mengisi Surat Pemberitahuan Pajak Tahunan (SPT).

\section{Tax Compliance}

Meskipun banyak penelitian tentang tax compliance (kepatuhan pajak), namun sangat sedikit penelitian yang mengobservasi kepatuhan, atau ketidakpatuhan pajak, terutama dengan perspektif etika. Kebanyakan dari penelitian tentang penggelapan pajak hanya melihat isu-isu dari perspektif keuangan publik atau ilmu ekonomi, meskipun isu-isu etika mungkin juga dikemukakan.

Penelitian yang dilakukan oleh McGee et al. (2011) menguji secara empiris opini dari praktisi akuntansi di Turki. Survei terhadap 176 praktisi akuntansi di Turki dilakukan untuk menjelaskan pendapat atas setuju sampai ketidaksetujuan terhadap 15 pertanyaan utama yang dikembangkan oleh Crow (1944) dan ditambah tiga pertanyaan yang baru sehingga terdapat 18 pertanyaan yang harus diberi peringkat oleh partisipan penelitian. Hasil penelitian tersebut adalah lebih banyak responden yang tidak setuju dengan penggelapan pajak dalam beberapa kasus. Penelitian tersebut juga menemukan bahwa penggelapan pajak terjadi karena pemerintah diduga melakukan korupsi dan sistem perpajakan yang dirasakan tidak adil. Kemudian, hal yang mungkin dilakukan adalah untuk mengurangi meluasnya penggelapan pajak adalah mengurangi korupsi di pemerintahan dan mendukung sistem pajak yang lebih adil. Temuan lainnya adalah praktisi akuntansi laki-laki di Turki lebih tidak setuju dengan penggelapan pajak daripada praktisi akuntansi perempuan. Kebanyakan penelitian lain menyebutkan bahwa perempuan lebih tidak setuju dengan penggelapan pajak daripada laki-laki. Selain itu, orang yang lebih tua lebih tidak setuju dengan penggelapan pajak daripada orang yang lebih muda.

Penelitian-penelitian tentang perilaku wajib pajak di Indonesia fokus pembahasannya masih banyak pada persepsi wajib pajak terhadap sistem perpajakan dan undangundang perpajakan. Penelitian yang dilakukan oleh Priono (2002) menunjukkan bahwa proses belajar, motivasi, dan kepribadian tidak berpengaruh positif terhadap pembentukan persepsi. Hasil lainnya menunjukkan bahwa perbedaan pengaruh variabel proses belajar, motivasi, dan kepribadian terhadap persepsi antara wajib pajak badan pengusaha kecil dan menengah menunjukkan perbedaan signifikan. Sedangkan untuk pengaruh persepsi terhadap pelaksanaan sistem self-assessment untuk pengusaha kecil dan menengah menunjukkan persepsi positif. Simpulan berikutnya tidak terdapat perbedaan persepsi mengenai undangundang ketentuan umum dan tata cara perpajakan dan pajak penghasilan antara pengusaha kecil dan menengah.

Penelitian yang dilakukan oleh Budiatmanto (1999) menunjukkan bahwa kepatuhan wajib pajak sesudah reformasi pajak tahun 1983 lebih baik dibandingkan dengan sebelum reformasi perpajakan tahun 1983, jika berdasarkan pada jumlah rupiah pajak terhimpun. Sementara berdasarkan jumlah wajib pajak yang terjaring, kepatuhan wajib pajak sesudah reformasi perpajakan tahun 1983 tidak lebih baik dibandingkan dengan sebelum reformasi perpajakan tahun 1983.

Suhardito (1996) menguji apakah faktor-faktor yang melekat pada wajib pajak, wajib pajak wiraswasta, dan wajib pajak nirwiraswasta berpengaruh terhadap keberhasilan penerimaan pajak bumi dan bangunan (PBB) di kota Surabaya.

Varosi et al. (2000) menguji apakah pengetahuan tentang situasi penggelapan pajak mempengaruhi kecenderungan seseorang 
untuk menghindari pajak. Hasil penelitian mereka mengindikasikan terdapat perubahan perilaku pembayar pajak ketika seorang penghindar pajak terlihat tidak bertanggung jawab secara sosial atau moral. Terjadi penurunan kecenderungan untuk menghindari pajak ketika partisipan memiliki pengetahuan tentang situasi penggelapan pajak yang dilakukan oleh penghindar pajak.

Hutama (2010) menguji pengaruh pengetahuan informasi penggelapan pajak dan prinsip moral pada kecenderungan penghindaran pajak. Hasil penelitian tersebut adalah pengetahuan informasi penggelapan pajak dapat menurunkan kecenderungan wajib pajak untuk menghindari pajak. Selain itu, penelitian tersebut menunjukkan bahwa wajib pajak dengan prinsip moral yang tinggi memiliki kecenderungan penghindaran pajak yang lebih rendah daripada wajib pajak dengan prinsip moral yang rendah.

Hutama (2010) tidak membedakan wajib pajak berdasarkan penghasilan. Dari hasil survei Kompas 13 Juni 2008 (Kompas.com) menunjukkan bahwa lebih banyak orang berpenghasilan rendah yang membayar PPh dibanding orang kaya. Meskipun penelitian Hutama (2010) berhasil mengidentifikasi bahwa pengetahuan informasi penggelapan pajak dan prinsip moral berpengaruh pada kecenderungan penghindaran pajak, namun tidak membedakan antara wajib pajak yang masuk kelompok berpenghasilan tinggi dan rendah.

Hutama (2011) menguji pengaruh pengetahuan informasi penggelapan pajak, prinsip moral, dan penghasilan pada kecenderungan penghindaran pajak. Hasil penelitian tersebut adalah pengetahuan wajib pajak terhadap informasi penggelapan pajak dapat menurunkan kecenderungan untuk menghindari pajak, baik pada wajib pajak yang berpenghasilan tinggi maupun rendah. Selain itu, wajib pajak dengan prinsip moral yang tinggi memiliki kecenderungan yang rendah untuk menghindari pajak, baik pada wajib pajak yang berpenghasilan tinggi maupun rendah.

\section{Ketidakpatuhan Wajib Pajak}

Ketidakpatuhan wajib pajak, seperti yang disebutkan oleh Jackson dan Jaouen (1989) (dalam Varosi, et al., 2000) merupakan masalah yang semakin meluas, baik besarannya maupun efek distribusinya pada wajib pajak. Kehilangan pendapatan dari sektor pajak merupakan bidang perhatian dari aparat pajak, dan ketidakpatuhan secara serius mempengaruhi integritas sistem pajak selfassessment. Temuan penelitian Spicer (1974) (dalam Varosi, et al., 2000) menemukan bahwa ketika pelalaian pajak menjadi meluas, wajib pajak yang jujur akan kehilangan kepercayaan terhadap sistem pajak yang ada dan menjadi orang yang tidak patuh pajak lagi.

Menurut Coleman (1987) (dalam Varosi, et al., 2000), berkembangnya ketidakpatuhan pajak merupakan fungsi respon otoritas pajak yang terbatas atas persepsi ketidakpatuhan. Penelitian Coleman tersebut menyatakan bahwa kesuksesan eksperimen yang dilakukan oleh Minnesota Department of Revenue difokuskan pada wajib pajak yang patuh sebagai sebuah norma dan wajib pajak yang tidak patuh merupakan sebagian kecil dari wajib pajak. Bukti awal ini mengindikasikan bahwa komunikasi memiliki pengaruh positif atas kelompok wajib pajak secara keseluruhan dalam eksperimen.

Teori keadilan dan teori perbandingan sosial berusaha menjelaskan ketidakpatuhan wajib pajak. Meskipun kedua teori ini bertolak belakang, namun keduanya memberikan dasar teori untuk menjelaskan ketidakpatuhan wajib pajak. Berikut penjelasan mengenai kedua teori tersebut.

\section{Prinsip Moral}

Forsyth (dalam Yetmar dan Eastman, 2000) menyarankan bahwa perbedaan 
individual dalam pendekatan terhadap pertimbangan moral didasarkan pada dua faktor prinsip moral yakni idealisme dan relativisme. Idealisme adalah tingkat di mana individu berkaitan dengan kesejahteraan bagi yang lain. Individu yang idealismenya tinggi merasakan mengganggu orang lain selalu dapat dihindarkan. Seorang yang idealis tidak akan memilih perilaku negatif yang dapat mengganggu orang lain. Hal yang sebaliknya terjadi jika nilai-nilai idealismenya rendah.

Sebaliknya, relativisme adalah penolakan aturan moral yang absolut dalam memandu perilaku. Individu yang relativismenya tinggi mengadopsi falsafah moral pribadi yang didasarkan pada skeptis. Mereka umumnya merasa bahwa tindakan moral tergantung pada sifat dan individu yang terlibat. Ketika menilai sesuatu, mereka menekankan aspek keadaan daripada prinsip etika yang dilanggar. Orang yang memiliki relativisme rendah berargumen bahwa moralitas memerlukan tindakan yang konsisten dengan prinsip moral, norma, dan hukum.

Konsep idealisme dan relativisme bukanlah hal yang berlawanan. Seorang relativis dapat juga sekaligus memiliki idealisme yang tinggi atau yang rendah. Prinsip moral (pada penelitian lain menyebutkan orientasi etika) yang diyakini individu terbukti mempunyai hubungan yang positif dengan keputusan perilaku etis (Husein, 2003). Ziegenfuss \& Singhapakdi (1994) dan Yetmar \& Eastman (2000) menguji dua bentuk dari prinsip moral yakni idealisme dan relativisme. Idealisme dan relativisme tidak berpengaruh pada perilaku etis. Pada penelitian Yetmar dan Eastman disebutkan bahwa relativisme berhubungan negatif dengan perilaku etis. Kedua peneliti menggunakan dua bentuk prinsip moral yang berasal dari Forsyth (dalam Yetmar dan Eastman, 2000). Walaupun hasil penelitian ini satu sama lain bertolak belakang, namun penelitian yang dilakukan oleh Husein (2003) dapat membuktikan bahwa terdapat hubungan yang positif antara prinsip moral yang diyakini individu dengan keputusan perilaku etis.

Yetmar dan Eastman (2000) juga menyatakan bahwa pengujian prinsip moral relativisme mengarah pada kategorisasi orientasi etika individual. Prinsip moral idealisme menunjukkan hasil pengujian yang tidak signifikan. Jika tingkat relativisme individual meningkat, individu tersebut cenderung untuk menolak peraturan moral yang absolut dalam berperilaku dan merasa bahwa tindakan moral individual tergantung pada situasi dan kondisi yang dialami individu yang bersangkutan. Oleh sebab itu, tingkat relativisme yang lebih tinggi menghalangi kemampuan individual untuk mengakui isu-isu etis.

Mengacu kepada penelitian yang dilakukan oleh Yetmar dan Eastman tersebut, penelitian ini menambahkan variabel personal values yang ditinjau dari prinsip moral relativisme. Penulis tidak mengukur prinsip moral idealisme karena menurut Yetmar dan Eastman (2000), penelitian-penelitian terdahulu menunjukkan bahwa pengukuran prinsip moral idealisme menunjukkan hasil yang tidak signifikan.

\section{Perumusan Hipotesis}

1. Tiga Opini dalam Etika Penggelapan Pajak Opini-opini yang ditemukan dalam literatur penggelapan pajak dapat dikelompokkan menjadi tiga kelompok, yaitu opini tidak etis (the unethical opinion), opini anarkis (the anarchist opinion), dan opini keadaan (the circumstance opinion). Opini-opini ini pertama kali dikembangkan oleh Crow (1994) (dalam Fagbemi et al. 2010 dan McGee et al. 2011).

\subsection{Opini Tidak Etis (The Unethical} Opinion)

Opini ini menyatakan bahwa penggelapan pajak selalu atau hamper selalu tidak etis. Cohn (1998) dan 
Smith dan Kimball (1998) dalam Fagbemi et al. (2010) menyebutkan bahwa terdapat tiga buah rasional yang mendasari opini ini. Alasan pertama yaitu percaya bahwa individu mempunyai tugas membayar pajak sesuai dengan permintaan negara. Sudut pandang ini secara luas diterapkan dalam demokrasi di mana ada kepercayaan yang kuat bahwa individu seharusnya mematuhi kesepakatan bersama. Alasan kedua, untuk membayar pajak sebagai tugas yang etis adalah individu mempunyai kewajiban kepada warga negara lain.

\subsection{Opini Anarkis (The Anarchist Opinion)}

Menurut Block (1993), opini ini berpendapat bahwa tidak pernah ada kewajiban untuk membayar pajak sebab negara tidak mempunyai legitimasi dan dianggap tidak bermoral sehingga tidak memiliki otoritas untuk mengambil apapun dari siapapun. Pada opini ini, negara dipandang sebagai mafia. Intinya adalah pajak dipandang sebagai pengambilan hak orang lain.

\subsection{Opini Keadaan (The Circumstance Opinion)}

Seseorang dengan opini ini beranggapan bahwa selalu ada alasan untuk melakukan penggelapan pajak. Beberapa dari penganut aliran ini memutuskan membayar pajak karena alasan moral, agama, dan kepercayaan. Selain itu, penggelapan pajak bisa saja etis dalam kondisi tertentu dan tidak etis pada kondisi yang lain.

\subsection{Hipotesis \\ Dari ketiga opini tersebut, dirumuskan hipotesis yang akan diuji untuk menjawab pertanyaan penelitian berikut ini. \\ $\mathrm{H}_{1}$ : Partisipan akan percaya bahwa penggelapan pajak terkadang etis. \\ $\mathrm{H}_{2}$ : Penggelapan pajak bisa lebih diterima ketika pemerintah dirasakan/diduga melakukan korupsi.}

\section{METODE PENELITIAN Desain Penelitian}

Penelitian ini menggunakan desain penelitian survei. Strategi penelitian ini perlu dipertimbangkan karena dinilai komprehensif dan mendetail dalam menyampaikan pertanyaan-pertanyaan yang digunakan peneliti dalam penelitian ini. Menurut Spector (1981) dan Denscombe (2003) (dalam McGee et al. 2011), desain penelitian ini bisa disebut efisien dalam pengumpulan informasi dari jumlah responden/partisipan yang cukup banyak dan dapat digunakannya teknik statistis untuk menjelaskan signifikansi statistis.

\section{Objek Penelitian}

Penekanan utama dari penelitian ini adalah memperoleh bukti-bukti etis dari penggelapan pajak dengan dengan menggali respon dari mahasiswa akuntansi S1 dan S2, dosen, dan karyawan, terutama di lingkungan FE UNY.

Subjek mahasiswa S1 adalah mahasiswa akuntansi semester akhir yang dusah lulus mata kuliah perpajakan. Demikian juga dengan subjek mahasiswa S2 akuntansi, yang diharapkan telah bekerja dan penghasilannya dipotong pajak penghasilan. Dengan demikian, subjek mahasiswa S1 dan S2 akuntansi ini dapat mewakili partisipan yang digolongkan sebagai wajib pajak. 
Varosi et al. (2000) mengungkapkan bahwa penelitian tentang kepatuhan pajak ( $\operatorname{tax}$ compliance research) sering menggunakan mahasiswa sebagai subjek penelitian. Untuk mengatasi pertanyaan apakah latar belakang pengalaman pajak partisipan mahasiswa dianggap representatif sebagai surogasi/pengganti dari pembayar pajak, Varosi et al. (2000) menggunakan cara mengumpulkan karakteristik demografi dan latar belakang pajak yang memenuhi relevansi pembayar pajak. Penelitian ini melakukan langkah yang serupa dengan apa yang dilakukan oleh Varosi et al. (2000) dengan memasukkan karakteristik pembayar pajak dalam mengumpulkan data demografi partisipan, seperti data penghasilan per bulan/tahun partisipan, status kepemilikan Nomor Pokok Wajib Pajak (NPWP), pembayaran pajak penghasilan, dan pernah atau tidaknya partisipan mengisi Surat Pemberitahuan Pajak Tahunan (SPT).

\section{Analisis}

\subsection{Uji Validitas dan Reliabilitas}

Suatu kuesioner dikatakan valid jika pertanyaan-pertanyaan pada kuesioner mampu untuk mengungkapkan sesuatu yang akan diukur oleh kuesioner tersebut. Untuk mengetahui bahwa pertanyaan-pertanyaan dalam variabelvariabel adalah valid (construct validity) maka dilakukan confirmatory factor analysis. Variabel-variabel diharapkan memiliki nilai Kaiser-Meyer-Olkin Measure of Sampling Adequacy (KMO MSA) >0,5 sehingga confirmatory factor analysis dapat dilakukan. Selain itu, nilai eigenvalue harus $>1$ dan masing-masing butir pertanyaan dari setiap variabel diharapkan memiliki factor loadings $\geq 0,40$ serta hanya menjadi anggota satu faktor (Hair, et al., 1998).

Sedangkan uji reliabilitas adalah alat untuk mengukur suatu kuesioner yang merupakan indikator dari variabel atau konstruk (Ghozali, 2005). Suatu kuesioner dikatakan reliabel atau handal jika jawaban seseorang terhadap pernyataan adalah konsisten atau stabil dari waktu ke waktu. Uji statistik Cronbach's Alpha $(\alpha)$ digunakan untuk mengukur reliabilitas. Suatu konstruk atau variabel dikatakan reliabel jika memberikan nilai Cronbach's Alpha $>0,60$ (Nunnally dalam Ghozali, 2005). Semakin tinggi nilai Cronbach's Alpha semakin tinggi reliabiltas sebuah kuesioner.

\subsection{Pengujian Hipotesis}

Hipotesis yang diformulasikan dalam penelitian ini diuji dengan pengujian statistis untuk mean populasi dan uji tingkat signifikansi. Asumsi yang digunakan adalah skor yang diperoleh dari pengumpulan data adalah berdistribusi normal, mengingat besarnya jumlah sampel. Penelitian ini juga berasumsi bahwa skor yang diperoleh dari setiap pernyataan di dalam kuesioner adalah independen antara satu pernyataan dengan pernyataan lainnya. Asumsi ini diperlukan untuk mendapatkan hasil penelitian yang tidak bias, seperti penelitian yang dilakukan McGee et al. (2011).

Penelitian ini akan berusaha merubah skor menjadi distribusi standar yang normal dan kemudian menghitung $z$-score (nilai z) untuk membuat inferensi setelah memperoleh p-value dari pernyataan-pernyataan dalam kuesioner, dengan tingkat signifikansi lima persen $(5 \%)$. Metoda yang diadopsi dalam penelitian ini konsisten dengan penelitian yang dilakukan oleh McGee $e t$ al. (2011) dan Fagbemi et al. (2010).

Instrumen yang digunakan dalam penelitian ini serupa dengan instrumen 
yang digunakan oleh McGee et al. (2011) dan Fagbemi et al. (2010). Instrumen survei terdiri dari 18 pernyataan yang merefleksikan tiga sudut pandang/opini etika dari penggelapan pajak yang muncul selama berabad-abad. Ketiga sudut pandang atau opini itu adalah opini tidak etis (the unethical opinion), opini anarkis (the anarchist opinion), dan opini keadaan (the circumstance opinion). Partisipan akan menjawab dengan cara memberi peringkat atas tingkat persetujuan mereka dari setiap pernyataan dengan memilih lima (5) kategori respon (skala Likert) dari sangat tidak setuju, tidak setuju, netral, setuju, dan sangat setuju ( $1=$ sangat setuju; $5=$ =sangat tidak setuju).

Delapan belas (18) pernyataan

yang merefleksikan tiga sudut pandang/opini etika dari penggelapan pajak yang pertama kali dikemukakan oleh Crow (1944) (dalam McGee et al. 2011 dan Fagbemi et al. 2010) sebanyak 15 pernyataan dan kemudian dikembangkan lagi oleh McGee et al. (2011) dan Fagbemi et al. (2010) dengan menambah tiga (3) pernyataan menjadi delapan belas (18) pernyataan. Berikut pernyataan-pernyataan tersebut:

1. Penggelapan pajak adalah etis ketika tarif pajak terlalu tinggi.

2. Penggelapan pajak adalah etis meskipun tarif pajak tidak terlalu tinggi sebab pemerintah sebenarnya tidak berhak mengambil hak saya terlalu banyak.

3. Penggelapan pajak adalah etis jika sistem pajak tidak adil.

4. Penggelapan pajak adalah etis jika jumlah uang yang besar dari pajak digunakan dengan tidak semestinya.
5. Penggelapan pajak adalah etis meskipun sebagian besar uang yang dikumpulkan dari pajak dibelanjakan dengan bijaksana.

6. Penggelapan pajak adalah etis jika jumlah uang yang besar dari pajak digunakan untuk proyek-proyek pemerintah yang secara moral saya tidak menyetujuinya.

7. Penggelapan pajak adalah etis meskipun sebagian besar uang yang dikumpulkan dari pajak dibelanjakan memang untuk proyek pembangunan yang pantas/seharusnya.

8. Penggelapan pajak adalah etis meskipun sebagian besar uang yang dikumpulkan dari pajak dibelanjakan untuk proyek pembangunan yang tidak mendatangkan manfaat buat saya.

9. Penggelapan pajak adalah etis meskipun sebagian besar uang yang dikumpulkan dari pajak dibelanjakan untuk proyek pembangunan yang jelas-jelas mendatangkan manfaat buat saya.

10. Penggelapan pajak adalah etis jika semua orang melakukannya.

11. Penggelapan pajak adalah etis jika jumlah uang pajak yang cukup banyak diduga masuk ke kantong politikus dan kroninya yang melakukan korupsi.

12. Penggelapan pajak adalah etis jikakemungkinan tertangkap oleh penegak hukum kecil.

13. Penggelapan pajak adalah etis jika sebagian warga negara mendukung dan berangkat perang (war) yang menurut saya perang itu mempunyai tujuan yang tidak benar/salah menurut saya. 
14. Penggelapan pajak adalah etis jika saya tidak mampu membayar pajak.

15. Penggelapan pajak adalah etis meskipun ketika saya membayar sedikit pajak, orang lain akan membayar pajak lebih banyak.

16. Penggelapan pajak bisa saja etis jika saya hidup dalam tekanan rezim seperti Nazi Jerman atau ISIS di sebagian timur tengah.

17. Penggelapan pajak adalah etis karena pemerintah diduga melakukan diskriminasi terhadap saya karena latar belakang agama, suku atau etnis.

18. Penggelapan pajak adalah etis jika pemerintah memenjarakan orangorang karena opini politik mereka.

Dari hasil kuesioner tersebut, kemudian dilakukan analisis dengan melakukan berikut ini:

1. Menghitung mean jawaban responden dari setiap pernyataan.

2. Membuat peringkat pernyataan dari yang sangat setuju sampai dengan sangat tidak setuju berdasarkan hasil mean setiap pernyataan.

3. Merubah skor menjadi distribusi standar yang normal dan kemudian menghitung z-score (nilai z) untuk membuat inferensi setelah memperoleh $p$-value dari pernyataanpernyataan dalam kuesioner, dengan tingkat signifikansi lima persen $(5 \%)$.

4. Untuk menguji hipotesis 1, hipotesis 1 akan didukung apabila $95 \%$ dari pernyataan mempunyai mean score lebih besar daripada 1 tapi kurang dari 5.

5. Untuk menguji hipotesis 2 , hipotesis 2 akan didukung apabila mean score pernyataan nomor 11 secara signifikan lebih besar daripada rata- rata score dari 17 pernyataan lainnya pada tingkat signifikansi lima persen $(5 \%)$.

\section{HASIL PENELITIAN DAN PEMBAHASAN}

Dalam penelitian survei ini, responden yang dikategorikan wajib pajak dipilih sebagai responden. Kuesioner adalah instrumen penelitian yang berisi 18 pernyataan. Pernyataan-pernyataan tersebut kemudian digunakan untuk memperoleh respon populasi terhadap ke-18 pernyataan tersebut, dengan menggunakan skala Likert dengan 5 kategori respon, dari sangat setuju (nilai satu), sampai sangat tidak setuju (nilai 5). Kuesioner ini dirancang untuk menjamin anonimitas, dengan kata lain, didesain untuk tidak mengenal identitas responden dan peneliti menjamin kerahasiaan data ini.

Sebanyak 100 kuesioner dibagikan, dari 100 kuesioner yang dibagikan tersebut, 100 kuesioner kembali namun 2 kuesioner tidak diisi lengkap, sehingga yang layak digunakan untuk pengolahan data adalah sebanyak 98 kuesioner. Jumlah data yang diperoleh untuk pengolahan ini (response rate) mencapai $98 \%$.

\section{Pengujian Persepsi bahwa Penggelapan Pajak terkadang Etis}

Hipotesis ini akan diterima jika 95\% dari pernyataan-pernyataan dalam instrumen memiliki mean score lebih dari satu (1) tetapi kurang dari lima (5). Oleh sebab itu, partisipan atau responden akan percaya bahwa penggelapan pajak terkadang etis (Tabel 4.1)

Seperti yang terlihat dari Tabel 4.1, perhitungan z-score yang diperoleh dari sebagian besar pernyataan menunjukkan probabilitas atau kemungkinan bahwa nilai rata-rata (mean score) akan jatuh antara 1 dan 5 adalah $100 \%$. Intinya adalah sudut pandang bahwa penggelapan pajak terkadang etis 
terlihat pada 18 dari 18 pernyataan yang digunakan dalam penelitian ini. Misalnya, pandangan/pernyataan bahwa penggelapan pajak adalah etis ketika hidup dalam tekanan rezim seperti Nazi Jerman atau ISIS di sebagian timur tengah adalah lazim dengan tingkat kepercayaan (confidence) 100\%, seperti yang terlihat dalam pernyataan nomor
16. Secara keseluruhan, hipotesis bahwa penggelapan pajak adalah terkadang etis ditolak pada tingkat signifikansi 5\%, tetapi diterima pada tingkat signifikan $10 \%$. Hanya pernyataan nomor 16 yang mendukung hipotesis 1.

Tabel 4.1 Perhitungan Skor Probabilitas antara 1 dan 5

\begin{tabular}{|c|r|r|r|r|r|r|r|l|}
\hline $\begin{array}{c}\text { No. } \\
\text { Pernya- } \\
\text { taan }\end{array}$ & Mean & $\begin{array}{c}\text { Std. } \\
\text { Dev. }\end{array}$ & $\begin{array}{c}\mathbf{z} \text {-score } \\
\text { untuk } \\
\mathbf{x}=\mathbf{1}\end{array}$ & $\begin{array}{c}\mathbf{z} \text {-score } \\
\mathbf{u n t u k} \\
\mathbf{x}=\mathbf{5}\end{array}$ & $\begin{array}{r}\mathbf{p} \text {-value }= \\
\mathbf{P}(\mathbf{1}<\mathbf{x}<\mathbf{x})\end{array}$ & $\begin{array}{l}\mathbf{p} \text {-value }= \\
\mathbf{P}(\mathbf{x}<\mathbf{x}<\mathbf{5})\end{array}$ & $\begin{array}{l}\mathbf{p} \text {-value }= \\
\mathbf{P}(\mathbf{1}<\mathbf{x}<\mathbf{5})\end{array}$ & $\begin{array}{l}\text { Hipotesis } \\
\mathbf{1}\end{array}$ \\
\hline 1 & 3,79 & 1,24 & $-2,25$ & 0,98 & 0,500 & 0,500 & 1,000 & $\begin{array}{l}\text { Tidak } \\
\text { Didukung }\end{array}$ \\
\hline 2 & 3,96 & 1,06 & $-2,78$ & 0,98 & 0,500 & 0,500 & 1,000 & $\begin{array}{l}\text { Tidak } \\
\text { Didukung }\end{array}$ \\
\hline 3 & 2,40 & 1,54 & $-0,91$ & 1,69 & 0,500 & 0,500 & 1,000 & $\begin{array}{l}\text { Tidak } \\
\text { Didukung }\end{array}$ \\
\hline 4 & 2,45 & 1,60 & $-0,91$ & 1,59 & 0,500 & 0,500 & 1,000 & $\begin{array}{l}\text { Tidak } \\
\text { Didukung }\end{array}$ \\
\hline 5 & 4,13 & 0,99 & $-3,16$ & 0,88 & 0,500 & 0,500 & 1,000 & $\begin{array}{l}\text { Tidak } \\
\text { Didukung }\end{array}$ \\
\hline 6 & 3,13 & 1,45 & $-1,47$ & 1,28 & 0,500 & 0,500 & 1,000 & $\begin{array}{l}\text { Tidak } \\
\text { Didukung }\end{array}$ \\
\hline 7 & 3,95 & 1,09 & $-2,71$ & 0,97 & 0,500 & 0,500 & 1,000 & $\begin{array}{l}\text { Tidak } \\
\text { Didukung }\end{array}$ \\
\hline 8 & 3,42 & 1,38 & $-1,76$ & 1,15 & 0,500 & 0,500 & 1,000 & $\begin{array}{l}\text { Tidak } \\
\text { Didukung }\end{array}$ \\
\hline 9 & 4,10 & 0,98 & $-3,17$ & 0,92 & 0,500 & 0,500 & 1,000 & $\begin{array}{l}\text { Tidak } \\
\text { Didukung }\end{array}$ \\
\hline 10 & 3,79 & 1,36 & $-2,05$ & 0,90 & 0,500 & 0,500 & 1,000 & $\begin{array}{l}\text { Tidak } \\
\text { Didukung }\end{array}$ \\
\hline 11 & 2,59 & 1,64 & $-0,97$ & 1,47 & 0,500 & 0,500 & 1,000 & $\begin{array}{l}\text { Tidak } \\
\text { Didukung }\end{array}$ \\
\hline 12 & 3,70 & 1,39 & $-1,95$ & 0,93 & 0,500 & 0,500 & 1,000 & $\begin{array}{l}\text { Tidak } \\
\text { Didukung }\end{array}$ \\
\hline 13 & 2,86 & 1,50 & $-1,24$ & 1,43 & 0,500 & 0,500 & 1,000 & $\begin{array}{l}\text { Tidak } \\
\text { Didukung }\end{array}$ \\
\hline 14 & 2,87 & 1,58 & $-1,18$ & 1,35 & 0,500 & 0,500 & 1,000 & $\begin{array}{l}\text { Tidak } \\
\text { Didukung }\end{array}$ \\
\hline 16 & 1,96 & 1,39 & $-0,69$ & 2,19 & 0,500 & 0,500 & 1,000 & $\begin{array}{l}\text { Tidak } \\
\text { Didukung }\end{array}$ \\
\hline Didukung \\
\hline
\end{tabular}


Jurnal Pendidikan Akuntansi Indonesia, Vol. XIV, No. 2, Tahun 2016

Isroah, Ponty, \& Amanita

$80-97$

\begin{tabular}{|c|c|c|c|r|r|r|r|r|}
\hline $\begin{array}{c}\text { No. } \\
\begin{array}{c}\text { Pernya- } \\
\text { taan }\end{array}\end{array}$ & Mean & $\begin{array}{c}\text { Std. } \\
\text { Dev. }\end{array}$ & $\begin{array}{c}\text { z-score } \\
\mathbf{u n t u k} \\
\mathbf{x = 1}\end{array}$ & $\begin{array}{c}\mathbf{z} \text {-score } \\
\mathbf{u n t u k} \\
\mathbf{x = 5}\end{array}$ & $\begin{array}{c}\mathbf{p - v a l u e =} \\
\mathbf{P}(\mathbf{1}<\mathbf{x}<\mathbf{x})\end{array}$ & $\begin{array}{c}\mathbf{p} \text {-value }= \\
\mathbf{P}(\mathbf{x}<\mathbf{x}<\mathbf{5})\end{array}$ & $\begin{array}{l}\mathbf{p} \text {-value = } \\
\mathbf{P}(\mathbf{1}<\mathbf{x}<\mathbf{5})\end{array}$ & $\begin{array}{c}\text { Hipotesis } \\
\mathbf{1}\end{array}$ \\
\hline 17 & 2,97 & 1,47 & $-1,34$ & 1,38 & 0,500 & 0,500 & 1,000 & $\begin{array}{l}\text { Tidak } \\
\text { Didukung }\end{array}$ \\
\hline 18 & 3,20 & 1,46 & $-1,51$ & 1,23 & 0,500 & 0,500 & 1,000 & $\begin{array}{l}\text { Tidak } \\
\text { Didukung }\end{array}$ \\
\hline
\end{tabular}

(1 = Sangat Setuju; 5 = Sangat Tidak Setuju $)$

Sumber: Survei Lapangan

Pengujian Persepsi bahwa Penggelapan Pajak bisa Diterima ketika Pemerintahan Dirasakan/Diduga Melakukan Korupsi

Hipotesis ini akan diterima jika nilai rata-rata (mean score) pernyataan nomor 11 secara signifikan lebih rendah daripada skor rata-rata tujuh belas (17) pernyataan lainnya. Seperti yang terlihat dari Tabel 4.2, perhitungan mean-score untuk pernyataan nomor 11 adalah 2,592. Intinya adalah mean score untuk pernyataan 11 menjadi tolak ukur dari mean score untuk 17 pernyataan lainnya. Implikasinya adalah bahwa pandangan responden untuk pernyataan nomor 16, 3, dan 4 dijastifikasi sebagai alasan yang bias dipandang etis untuk melakukan penggelapan pajak. Pernyataan 16 adalah mengenai rezim pelanggar hak asasi manusia, pernyataan 3 adalah ketidakadilan dalam sistem pajak, dan pernyataan 4 adalah penggunaan pajak yang tidak semestinya.

Secara keseluruhan, penelitian ini telah menemukan bahwa persepsi penggelapan pajak akan menjadi etis/bisa lebih diterima ketika pemerintah dirasakan/diduga melakukan korupsi. Sedangkan persepsi yang secara signifikan merupakan persepsi yang paling bisa diterima responden daripada persepsi yang lain yang diungkapkan dalam 17 pernyataan lainnya adalah pernyataan nomor 16 mengenai rezim pelanggar hak asasi manusia.
Tabel 4.2 Perbandingan Mean Score setiap Pernyataandengan Mean Score untuk Pemerintahan yang Diduga Korup (Pernyataan 11)

\begin{tabular}{|c|c|c|l|}
\hline $\begin{array}{c}\text { No. } \\
\text { Pernya } \\
\text { taan }\end{array}$ & Mean & $\begin{array}{c}\text { Std. } \\
\text { Dev. }\end{array}$ & \multicolumn{1}{|c|}{ Hipotesis 2 } \\
\hline 1 & 3,786 & 1,237 & Tidak Didukung \\
& & & \\
2 & 3,959 & 1,064 & Tidak Didukung \\
3 & 2,398 & 1,538 & Didukung \\
4 & 2,449 & 1,600 & Didukung \\
5 & 4,133 & 0,991 & Tidak Didukung \\
6 & 3,133 & 1,455 & Tidak Didukung \\
7 & 3,949 & 1,088 & Tidak Didukung \\
8 & 3,418 & 1,377 & Tidak Didukung \\
9 & 4,102 & 0,979 & Tidak Didukung \\
10 & 3,786 & 1,357 & Tidak Didukung \\
11 & 2,592 & 1,642 & - \\
12 & 3,704 & 1,386 & Tidak Didukung \\
13 & 2,857 & 1,499 & Tidak Didukung \\
14 & 2,867 & 1,584 & Tidak Didukung \\
15 & 3,735 & 1,117 & Tidak Didukung \\
16 & 1,959 & 1,392 & Didukung \\
17 & 2,969 & 1,475 & Tidak Didukung \\
18 & 3,204 & 1,457 & Tidak Didukung \\
\hline
\end{tabular}

( 1 = Sangat Setuju; 5 = Sangat Tidak Setuju $)$ Sumber: Survei Lapangan 


\section{Hasil Temuan Lain}

1.1. Peringkat dari Argumentasi Etis untuk Penggelapan Pajak

Dari Tabel 4.3, ditampilkan berbagai argumentasi responden dalam memberikan pembenaran terhadap penggelapan pajak. Lima (5) argumentasi teratas dalam membenarkan penggelapan pajak adalah; korupsi pemerintah (pernyataan 11), penggunaan pajak dengan tidak sebagaimana mestinya (pernyataan 4), tarif pajak yang terlalu tinggi (pernyataan 1), sistem pajak yang tidak adil (pernyataan 3), dan kemungkinan dihukum/tertangkap karena menggelapkan pajak adalah kecil (pernyataan 12).

Ini menunjukkan bahwa respon pemerintah dalam hal akuntabilitas, transparansi, tarif pajak yang optimal, keadilan, dan hukuman bagi pelaku penggelapan pajak memainkan peran yang sangat penting dalam pembayaran pajak oleh wajib pajak.

Tabel 4.3 Peringkat dari Argumen Etis untuk Penggelapan Pajak

\begin{tabular}{|c|c|c|c|}
\hline $\begin{array}{c}\text { Peri } \\
\text { ngk } \\
\text { at/ } \\
\text { Ran } \\
\text { king }\end{array}$ & $\begin{array}{c}\text { No. } \\
\text { Pernya } \\
\text { taan }\end{array}$ & Pernyataan & $\begin{array}{l}\text { Mean } \\
\text { Score }\end{array}$ \\
\hline 1 & 16 & $\begin{array}{l}\text { Penggelapan } \\
\text { pajak bisa saja } \\
\text { etis jika saya } \\
\text { hidup dalam } \\
\text { tekanan rezim } \\
\text { seperti Nazi } \\
\text { Jerman atau ISIS } \\
\text { di sebagian timur } \\
\text { tengah. }\end{array}$ & $\begin{array}{l}1,9591 \\
83673\end{array}$ \\
\hline
\end{tabular}

\begin{tabular}{|c|c|c|c|}
\hline $\begin{array}{l}\text { Peri } \\
\text { ngk } \\
\text { at/ } \\
\text { Ran } \\
\text { king }\end{array}$ & $\begin{array}{l}\text { No. } \\
\text { Pernya } \\
\text { taan }\end{array}$ & Pernyataan & $\begin{array}{l}\text { Mean } \\
\text { Score }\end{array}$ \\
\hline 2 & 3 & $\begin{array}{l}\text { Penggelapan } \\
\text { pajak adalah etis } \\
\text { jika sistem pajak } \\
\text { tidak adil. }\end{array}$ & $\begin{array}{r}2,3979 \\
59184\end{array}$ \\
\hline 3 & 4 & $\begin{array}{l}\text { Penggelapan } \\
\text { pajak adalah etis } \\
\text { jika jumlah uang } \\
\text { yang besar dari } \\
\text { pajak digunakan } \\
\text { dengan tidak } \\
\text { semestinya. } \\
\end{array}$ & $\begin{array}{r}2,4489 \\
79592\end{array}$ \\
\hline 4 & 11 & $\begin{array}{l}\text { Penggelapan } \\
\text { pajak adalah etis } \\
\text { jika jumlah uang } \\
\text { pajak yang cukup } \\
\text { banyak diduga } \\
\text { masuk ke kantong } \\
\text { politikus dan } \\
\text { kroninya yang } \\
\text { melakukan } \\
\text { korupsi. }\end{array}$ & $\begin{array}{l}2,5918 \\
36735\end{array}$ \\
\hline 5 & 13 & $\begin{array}{l}\text { Penggelapan } \\
\text { pajak adalah etis } \\
\text { jika sebagian } \\
\text { warga negara } \\
\text { mendukung dan } \\
\text { berangkat perang } \\
\text { (war) yang } \\
\text { menurut saya } \\
\text { perang itu } \\
\text { mempunyai } \\
\text { tujuan yang tidak } \\
\text { benar/salah } \\
\text { menurut saya. }\end{array}$ & $\begin{array}{r}2,8571 \\
42857\end{array}$ \\
\hline 6 & 14 & $\begin{array}{l}\text { Penggelapan } \\
\text { pajak adalah etis } \\
\text { jika saya tidak } \\
\text { mampu } \\
\text { membayar pajak. }\end{array}$ & $\begin{array}{r}2,8673 \\
46939\end{array}$ \\
\hline
\end{tabular}


Jurnal Pendidikan Akuntansi Indonesia, Vol. XIV, No. 2, Tahun 2016

Isroah, Ponty, \& Amanita

$80-97$

\begin{tabular}{|c|c|c|c|}
\hline $\begin{array}{c}\text { Peri } \\
\text { ngk } \\
\text { at/ } \\
\text { Ran } \\
\text { king }\end{array}$ & $\begin{array}{c}\text { No. } \\
\text { Pernya } \\
\text { taan }\end{array}$ & Pernyataan & $\begin{array}{l}\text { Mean } \\
\text { Score }\end{array}$ \\
\hline 7 & 17 & $\begin{array}{l}\text { Penggelapan } \\
\text { pajak adalah etis } \\
\text { karena } \\
\text { pemerintah } \\
\text { diduga melakukan } \\
\text { diskriminasi } \\
\text { terhadap saya } \\
\text { karena latar } \\
\text { belakang agama, } \\
\text { suku atau etnis. }\end{array}$ & $\begin{array}{l}2,9693 \\
87755\end{array}$ \\
\hline 8 & 6 & $\begin{array}{l}\text { Penggelapan } \\
\text { pajak adalah etis } \\
\text { jika jumlah uang } \\
\text { yang besar dari } \\
\text { pajak digunakan } \\
\text { untuk proyek- } \\
\text { proyek } \\
\text { pemerintah yang } \\
\text { secara moral saya } \\
\text { tidak } \\
\text { menyetujuinya. }\end{array}$ & $\begin{array}{l}3,1326 \\
53061\end{array}$ \\
\hline 9 & 18 & $\begin{array}{l}\text { Penggelapan } \\
\text { pajak adalah etis } \\
\text { jika pemerintah } \\
\text { memenjarakan } \\
\text { orang-orang } \\
\text { karena opini } \\
\text { politik mereka } \\
\end{array}$ & $\begin{array}{l}3,2040 \\
81633\end{array}$ \\
\hline 10 & 8 & $\begin{array}{l}\text { Penggelapan } \\
\text { pajak adalah etis } \\
\text { meskipun } \\
\text { sebagian besar } \\
\text { uang yang } \\
\text { dikumpulkan dari } \\
\text { pajak } \\
\text { dibelanjakan } \\
\text { untuk proyek } \\
\text { pembangunan } \\
\text { yang tidak }\end{array}$ & $\begin{array}{r}3,4183 \\
67347\end{array}$ \\
\hline
\end{tabular}

\begin{tabular}{|c|c|c|c|}
\hline $\begin{array}{l}\text { Peri } \\
\text { ngk } \\
\text { at/ } \\
\text { Ran } \\
\text { king }\end{array}$ & $\begin{array}{l}\text { No. } \\
\text { Pernya } \\
\text { taan }\end{array}$ & Pernyataan & $\begin{array}{l}\text { Mean } \\
\text { Score }\end{array}$ \\
\hline & & $\begin{array}{l}\text { mendatangkan } \\
\text { manfaat buat } \\
\text { saya. }\end{array}$ & \\
\hline 11 & 12 & $\begin{array}{l}\text { Penggelapan } \\
\text { pajak adalah etis } \\
\text { jikakemungkinan } \\
\text { tertangkap oleh } \\
\text { penegak hukum } \\
\text { kecil. }\end{array}$ & $\begin{array}{l}3,7040 \\
81633\end{array}$ \\
\hline 12 & 15 & $\begin{array}{l}\text { Penggelapan } \\
\text { pajak adalah etis } \\
\text { meskipun ketika } \\
\text { saya membayar } \\
\text { sedikit pajak, } \\
\text { orang lain akan } \\
\text { membayar pajak } \\
\text { lebih banyak. }\end{array}$ & $\begin{array}{l}3,7346 \\
93878\end{array}$ \\
\hline 13 & 1 & $\begin{array}{l}\text { Penggelapan } \\
\text { pajak adalah etis } \\
\text { ketika tarif pajak } \\
\text { terlalu tinggi. }\end{array}$ & $\begin{array}{r}3,7857 \\
14286\end{array}$ \\
\hline 13 & 10 & $\begin{array}{l}\text { Penggelapan } \\
\text { pajak adalah etis } \\
\text { jika semua orang } \\
\text { melakukannya. }\end{array}$ & $\begin{array}{r}3,7857 \\
14286\end{array}$ \\
\hline 15 & 7 & $\begin{array}{l}\text { Penggelapan } \\
\text { pajak adalah etis } \\
\text { meskipun } \\
\text { sebagian besar } \\
\text { uang yang } \\
\text { dikumpulkan dari } \\
\text { pajak } \\
\text { dibelanjakan } \\
\text { memang untuk } \\
\text { proyek } \\
\text { pembangunan } \\
\text { yang } \\
\text { pantas/seharusnya } \\
\text {. }\end{array}$ & $\begin{array}{l}3,9489 \\
79592\end{array}$ \\
\hline
\end{tabular}




\begin{tabular}{|c|c|c|c|}
\hline $\begin{array}{c}\text { Peri } \\
\text { ngk } \\
\text { at/ } \\
\text { Ran } \\
\text { king }\end{array}$ & $\begin{array}{c}\text { No. } \\
\text { Pernya } \\
\text { taan }\end{array}$ & Pernyataan & $\begin{array}{l}\text { Mean } \\
\text { Score }\end{array}$ \\
\hline 16 & 2 & $\begin{array}{l}\text { Penggelapan } \\
\text { pajak adalah etis } \\
\text { meskipun tarif } \\
\text { pajak tidak terlalu } \\
\text { tinggi sebab } \\
\text { pemerintah } \\
\text { sebenarnya tidak } \\
\text { berhak } \\
\text { mengambil hak } \\
\text { saya terlalu } \\
\text { banyak. }\end{array}$ & $\begin{array}{l}3,9591 \\
83673\end{array}$ \\
\hline 17 & 9 & $\begin{array}{l}\text { Penggelapan } \\
\text { pajak adalah etis } \\
\text { meskipun } \\
\text { sebagian besar } \\
\text { uang yang } \\
\text { dikumpulkan dari } \\
\text { pajak } \\
\text { dibelanjakan } \\
\text { untuk proyek } \\
\text { pembangunan } \\
\text { yang jelas-jelas } \\
\text { mendatangkan } \\
\text { manfaat buat saya }\end{array}$ & $\begin{array}{l}4,1020 \\
40816\end{array}$ \\
\hline 18 & 5 & $\begin{array}{l}\text { Penggelapan } \\
\text { pajak adalah etis } \\
\text { meskipun } \\
\text { sebagian besar } \\
\text { uang yang } \\
\text { dikumpulkan dari } \\
\text { pajak } \\
\text { dibelanjakan } \\
\text { dengan bijaksana. }\end{array}$ & $\begin{array}{l}4,1326 \\
53061\end{array}$ \\
\hline
\end{tabular}

(1 = Sangat Setuju; 5 = Sangat Tidak Setuju)

Sumber: Survei Lapangan

\section{SIMPULAN DAN SARAN}

Penyediaan infrastruktur dasar sangat diperlukan untuk pembangunan dan pertumbuhan dalam masyarakat manapun. Infrastruktur ini benar-benar membutuhkan banyak dana yang tidak mungkin dipenuhi oleh beberapa satu individu. Oleh karena itu, pemerintah seharusnya menunjukkan perhatian besar pada upaya-upaya memperoleh dana pembangunan untuk mencapai tujuan-tujuan yang ditetapkan oleh masyarakat. Salah satu caranya adalah melalui perpajakan.

Oleh karena itu, warga negara diharapkan bertanggungjawab kepada negara dengan membayar pajak karena akan memberikan kontribusi bagi pembangunan masyarakat pada umumnya. Namun, infrastruktur dasar yang seharusnya disediakan untuk seluruh masyarakat tidak tersedia dan/atau berada dalam kondisi yang tidak layak. Sering kali pula, pemerintah mengeluh dan menyatakan bahwa penghindaran pajak berkontribusi dalam sebagian besar dari kegagalan ini. Dengan demikian, penelitian ini berangkat untuk melihat perilaku etis wajib pajak untuk menghindari pajak.

Populasi sampel sebanyak 98 orang di Universitas Negeri Yogyakarta dalam kurun waktu September-Oktober tahun 2016, digunakan dalam melakukan penelitian ini. Data primer digunakan untuk mencapai tujuan penelitian. Penelitian ini menunjukkan bahwa terdapat alasan etis mengapa wajib pajak melalaikan pajak, dengan kata lain, alasan etis untuk penggelapan pajak akan selalu ada dan dijastifikasi oleh wajib pajak.

Penelitian ini juga menemukan bahwa terdapat masalah etika yang luas untuk penggelapan pajak. Penelitian ini menunjukkan berbagai tingkat pembenaran untuk penggelapan pajak seperti yang ditunjukkan oleh nilai rata-rata (mean score). Responden percaya bahwa 
penggelapan pajak terkadang etis pada tingkat kepercayaan mencapai $90 \%$.

Selain itu, penelitian ini juga menemukan bahwa ketika responden merasakan/menduga bahwa jika di suatu negara dipimpin oleh rezim pelanggar hak asasi manusia, maka responden mempunyai persepsi bahwa menggelapkan pajak adalah suatu tindakan yang bisa disebut etis, juga masalah keadilan, penggunaan pajak yang tidak semestinya, dan rezim yang koruptif (tabel 4.3). Oleh karena itu, jika masalah hak asasi manusia, keadilan, penggunaan pajak yang tidak semestinya, dan korupsi ini tidak ditangani dengan baik, penggelapan pajak dapat terus meluas, dan pada akhirnya akan merugikan negara. Oleh sebab itu, penelitian ini merekomendasikan beberapa hal berikut:

1. Pemerintah harus berusaha untuk memastikan bahwa mereka bertanggungjawab dan transparan dalam penyelenggaraan administrasi publik.

2. Pemerintah juga harus memberi perhatian khusus terhadap sistem pajak dengan memastikan bahwa itu sistem pajak tersebut adil untuk semua warga negara.

3. Upaya-upaya yang membuat jera pelaku penggelapan pajak perlu diterapkan dengan tegas dan serius. Demikian juga bagi yang taat pajak, dapat dipertimbangkan untuk mendapatkan benefit/manfaat lebih.

4. Penelitian ini dapat direplikasi dengan beberapa cara. Pendapat mahasiswa teologi dan mahasiswa bisnis mungkin menjadi topik yang menarik untuk dipelajari dan mengeksplorasi pengaruh pendidikan dan agama pada penggelapan pajak. Pendapat mahasiswa hukum juga perlu dieksplorasi, karena mereka cenderung menjadi pengamat dari aturan yang ketat, yang sesuai dengan pelatihan yang mereka jalani.

5. Penelitian ini mempunyai implikasi dengan merubah arah penelitianpenelitian selanjutnya, dimana penelitian-penelitian sebelumnya fokus pada mengapa wajib pajak tidak patuh pajak, menjadi fokus pada mengapa wajib pajak patuh pajak.

\section{DAFTAR PUSTAKA}

Block, W. 1993. Public Finance Texts Cannot Justify Government Taxation: A Critique. Canadian Public Administration/Administration

Publique du Canada Vol. 36 No. 2: 225-262.

Budiatmanto, Agus. 1999. Studi Evaluasi Kepatuhan Wajib Pajak Sebelum dan Sesudah Reformasi Perpajakan Tahun 1983 (Studi pada Kantor Wilayah VIII Direktorat Jendral Pajak Jawa Tengah dan Daerah Istimewa Yogyakarta). Tesis. Program Pascasarjana Universitas Gadjah Mada, Yogyakarta. Fafunwa, A.B. 2005. Collapse in Educational System: Our Collective Failure. The Guardian (October): 13.

Fagbemi, Temitope Olamide, Olayinka Marte Uadiale, dan Abdurafiu Olaiya Noah. 2010. The Ethics of Tax Evasion: Perceptual Evidence from Nigeria. Eropean Journal of Social Sciences Vol. 17 No. 3.

Ghozali, Imam. 2005. Aplikasi Analisis Multivariate dengan Program SPSS. Badan Penerbit Universitas Diponegoro, Semarang.

Hair, Joseph F., et al. 1998. Multivariate Data Analysis. Prentice-Hall, Inc., New Jersey.

Heru, Rudy Gunarso. 1997. Peran Perencanaan Pajak untuk Menghasilkan Penghematan Pajak (Studi Kasus Industri Sepatu PT. ISR). 
Tesis. Program S2 MBA Technology Institut Bandung, Bandung.

Husein, M. Fakhri. 2003. Keterkaitan FaktorFaktor Organisasional, Individual, Konflik Peran, Perilaku Etis Dan Kepuasan Kerja Akuntan Manajemen. Tesis. Pascasarjana Universitas Gadjah Mada, Yogyakarta.

Hutama, Ponty Sya'banto Putra. 2010. The Influence of the Awareness of the Information on Tax Evasion and Moral Principle towards the Propensity of Tax Evasion: An Experimental Study. The Indonesian Journal of Accounting Research Vol. 13 No. 1 (January).

Hutama, Ponty Sya'banto Putra. 2011. Pengaruh Pengetahuan Informasi PenggelapanPajak, Prinsip Moral, dan Penghasilan pada Kecenderungan Penghindaran Pajak: Sebuah Eksperimen. Laporan Hasil Penelitian Hibah Kopertis V, Yogyakarta.

McCrohan, Kevin F. dan Timothy F. Sugrue. 1998. An Empirical Analysis of Informal Market Participation. Sosial Science Quarterly Vol. 79 No. 1 (March): 212-226.

McGee, Robert W., Serkan Benk, Halil Yildirim, dan Murat Kayikci. 2011. TheEthics of Tax Evasion: A Study of Turkish Tax Practition Opinion. European Journal of Social Sciences Vol. 18 No. 3.

Mukur, G.A. 2001. Design of Tax Systems and Corruption, Conference Paper on Fighting Corruption: Common Challenges and Shared Experiences. Konard Adenauer Stiftung and the Institute of International Affairs (SIIA), Singapore (May): 1-9.

Nightingale, K. 1997. Taxation: Theory and Practice. Pitman, United Kingdom.
Obaji, C. 2005. Nigeria Cannot Justify 40 billion Spent on Education. The Punch (October):19.

Priono, Hero. 2002. Pemahaman Wajib Pajak Badan terhadap Pelaksanaan Sistem Self Assessment (Studi Terhadap Pengusaha Kecil dan Menengah di Surabaya). Tesis. Program Pascasarjana Universitas Gadjah Mada, Jogjakarta.

Song, Young-dahl dan Tinsley E. Yarbrough. 1978. Tax Ethics and Taxpayer Attitudes: A Survey. Public Administration Review 38 (September/October): 442-460.

Soyode, L. dan S.O. Kajola. 2006. Taxation: Principles and Practice in Nigeria. $1^{\text {st }}$ Edition, Silicon, Ibadan.

Spicer, Michael W. dan Lee A. Becker. 1980. Fiscal Inequity and Tax Evasion: An Experimental Approach. National Tax Journal Vol. 33 No. 2: 171-175.

Suhardito, Bambang. 1996. Pengaruh FaktorFaktor yang Melekat Pada Wajib Pajak terhadap Keberhasilan Penerimaan Pajak Bumi dan Bangunan (PBB). Tesis. Program Pascasarjana Universitas Gadjah Mada, Yogyakarta. Varosi, Terry R., Bonnie K. Klamm, dan Kevin F. McCrohan. 2000. The Effect of a Salient Tax Avoidance Situation On Propensity to Evade Income Taxes. Research On Accounting Ethics Vol. 7: 65-81.

Yetmar, Scott A. dan Kenneth K. Eastman. 2000. Tax Practitioners' Ethical Sensitivity: A Model and Empirical Examination. Journal of Business Ethics Vol. 26: 271-288.

Ziegenfuss, Douglas E. dan Anusorn Singhapakdi. 1994. Professional Values and The Ethical Perceptions of Internal Auditors. Managerial Auditing Journal Vol. 9: 34-44. 